\title{
Mosul Dam: A Catastrophe Yet to Unfold
}

\author{
Nasrat Adamo', Nadhir Al-Ansari', Sven Knutsson', Jan Laue1, Varoujan Sissakian² \\ ${ }^{1}$ Lulea University of Technology, Lulea, Sweden \\ ${ }^{2}$ Private Consultant, Erbil, Iraq \\ Email: nasrat.adamo@yahoo.com,nadhir.alansari@ltu.se,Sven.Knutsson@ltu.se,jan.laue@ltu.se,varoujan49@yahoo.com
}

How to cite this paper: Adamo, N., Al-Ansari, N., Kmutsson, S., Laue, J. and Sissakian, V. (2017) Mosul Dam: A Catastrophe Yet to Unfold. Engineering, 9, 263278.

https://doi.org/10.4236/eng.2017.93014

Received: March 8, 2017

Accepted: March 28, 2017

Published: March 31, 2017

Copyright (C) 2017 by authors and Scientific Research Publishing Inc. This work is licensed under the Creative Commons Attribution International License (CC BY 4.0).

http://creativecommons.org/licenses/by/4.0/

\section{cc) (i) Open Access}

\begin{abstract}
Mosul Dam is multipurpose earth fill dam. It is $3.4 \mathrm{~km}$ long, $113 \mathrm{~m}$ in height and its storage capacity reaches $11.11 \mathrm{~km}^{3}$ of which $2.95 \mathrm{~km}^{3}$ is dead storage. The dam is located on the River Tigris in the northern part of Iraq about 60 $\mathrm{km}$ in north west Mosul city. The dam was built on highly karstified alternating beds of gypsum, marl and limestone. The dam was operating in 1986 and since then, seepage problems started due to the solubility of the gypsum beds, presence of karstification and the effect of the local groundwater aquifer. Insensitive grouting program was put to stop the seepage and ensure the stability of the dam but it did not stop. The situation became worse in 2014 when ISIS occupied the dam area and grouting operations which were halted. Recent evaluation of the conditions indicates that the dam is in its worst conditions. The failure models of the dam indicate that 6 million people will be affected, and $7202 \mathrm{~km}^{2}$ of land will be inundated. To stop this catastrophe, grouting operations should be continued intensively to elongate the span life of the dam. Water level within its reservoir should be kept at a very low level to minimize the damages in case of dam failure. As a permanent solution, another dam should be built downstream Mosul Dam so that it can take the wave of Mosul Dam in case of its failure.
\end{abstract}

\section{Keywords}

Iraq, Tigris River, Mosul Dam, Grouting, Karstification

\section{Introduction}

Mosul dam is one of the largest dams in the Middle East, with an impoundment of 11.1 billion cubic meters; it adds to Iraq's water resources another 8.16 billion cubic meters of live storages. In an arid country like Iraq, this quantity is badly needed for irrigating 1 million hectares of fertile land while at the same time it utilizes $750 \mathrm{Mw}$. power station to generate electricity without taking into account of $60 \mathrm{Mw}$. installed in its reregulating dam (8 kilometers south of the main 
dam) and another $200 \mathrm{Mw}$. installed in the pump storage scheme on its right shoulder. Mosul Dam is located in the north of Iraq $\left(42^{\circ} 49^{\prime} 19^{\prime \prime} \mathrm{E}, 36^{\circ} 37^{\prime} 48^{\prime \prime} \mathrm{N}\right)$. It has been known all the time that the dam's foundation suffers from problems which are related to its prehistoric origins. Continents were formed during the ancient geological ages from movement and collision of earth plates. Iraq is located on the northern edge of the Arabian shield which collided with the Eurasian plate giving rise to Taurus and Zagros mountain ridges. The north of Iraq itself was formed by the continuous fluctuation of the seas, sedimentation and evaporation processes. Therefore, the geology of the north of Iraq is dominated by mudstone, limestone, and Evaporites (Gypsum and Anhydrite). Mosul Dam site foundations are characterized by these types of rocks in a very advanced state of karstification due to the continued flow of ground water over history, which gave rise to the present problems.

\section{Historical Overview}

The first step to build the dam was taken by the Iraq Development Board in 1952. A joint venture of two British firms was selected to prepare a preliminary study by performing some investigations and selected a dam site and drew up a final design. The objectives of the dam at that time were for flood protection and saving water to irrigate $\mathrm{Al}$ Jazera Project. These objectives were changed later on by adding more land for irrigation and also by requiring power generation. This led to asking three more consulting firms one after the other to prepare the required designs until finally it rested with the Swiss Consultant Consortum in 1978 to do the designs and tender documents (Figure 1). All the consultants had recognized the presence of soluble gypsum in the foundations which resulted in selecting various dam axes locations and different designs, but they all agreed that grouting would solve the problem of dissolution of gypsum [1]. We can say that all of them had shown the same degree of misjudgment of these conditions in spite of the extensive geological investigations which have been carried out.

This paper is the result of the condensation of results and analyses of a huge number of studies and reports compiled by the authors on the observations and analyses of the various geological phenomena and the related problems appearing

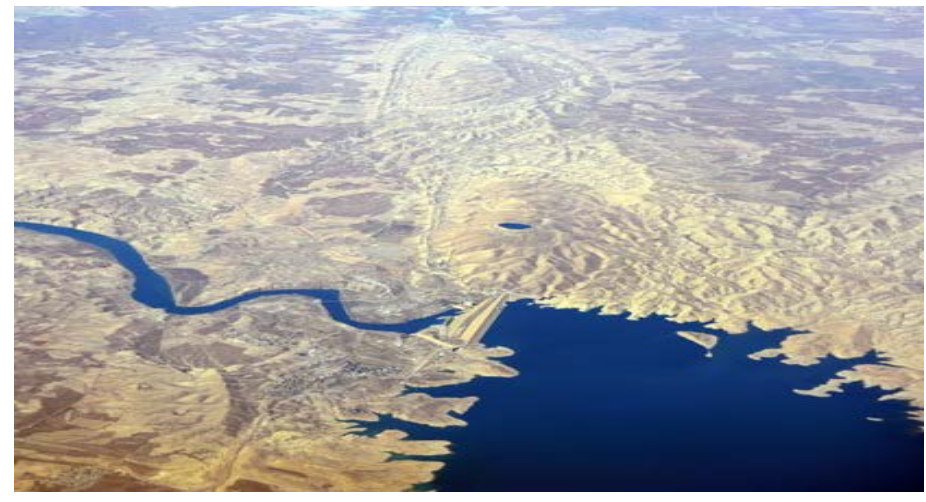

Figure 1. Showing the embankment and appurtenant structures, pump storage upper reservoir and part of the reservoir. 
during the construction and operation of Mosul Dam over the past thirty six years. In all these years the authors have been directly and actively engaged in conducting individually and with others much research work towards the understanding of these phenomena and proposing solutions. The views and comments which appear in this paper are direct results of their involvement and research.

\section{Geological Conditions of Dam Foundations}

The design envisaged the use of grouting to protect the foundation of the dam against seepage and the dissolution of gypsum; it did not take into account what could happen in the close proximity around the dam of such dissolution. As one would imagine problems did occur in both the foundation of the dam itself and around it. The anti-seepage measures taken by the construction were blanket grouting under the clay core and a deep curtain under the dam. The blanket had the depth varying from 10 meters at the outside edges to 25 meters at the centerline.

The deep grout curtain had a depth of 80 - 100 meters in the deep section of the river where the worst karstified rock formations existed. Under the main dam a karst level line was defined during investigations which showed the extent to which weathering and Karstification process worked its way down. The most affected bed formations above this line were the gypsum/Anhydrite beds and the transitional gypsum breccia (GB) in addition to brecciated marls (marls with gypsiferous cement). The four gypsum breccia layers had varying thicknesses between 8 and 18 meters and were designated from downwards up as (GB0), (GB1), (GB2), (GB3) [2]. The importance of these layers stems from being very difficult to grout and if they happen to be somehow grouted they soon lose the grout material and start to erode and dissolve under the effect of seepage water. Figure 2 shows geological section on the dam axis extending from east at the top left corner to west at the bottom right corner. It is constructed based on geologist's field notes and inspection of rock cores recovered from the previous investigation works in addition to water permeably tests executed using the Lugeon method. Employing the same procedure and methods a line which was called the karsts line marking the boundary between the highly kartsified layers above it from the less kartsified and less permeable layers below it. This is shown in Figure 3 and it was used as a guideline to establish the depth of the grout curtain [3] [4].

In the left bank and under the saddle dam, the foundation was not any better than the main dam described above (Figure 4). Although it did not suffer much kartsification, the (F-Bed) limestone layer dominating the upper 30 meters was very much cracked and fissured and it formed open conduits to seepage water down to the river bank and to the more solid (GB3) layer below it. This layer was uncovered during the excavation of spillway chute and bucket's foundations and represented a dissolution hazard as it contained very wide cracks and joints as shown in Figure 4. 


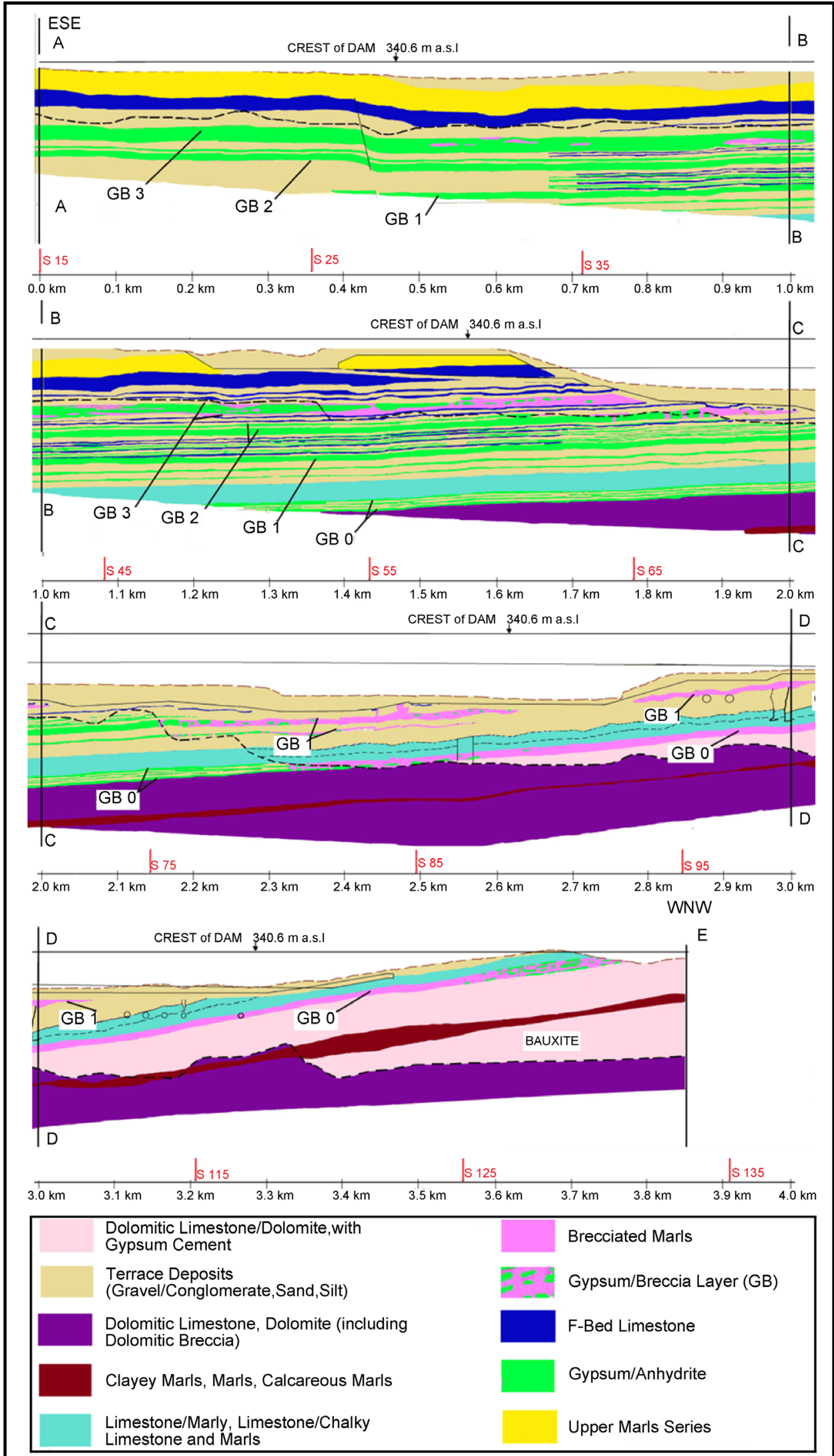

Figure 2. Geological section starts from (East) at upper left corner to (West) at bottom lower corner [3]. 


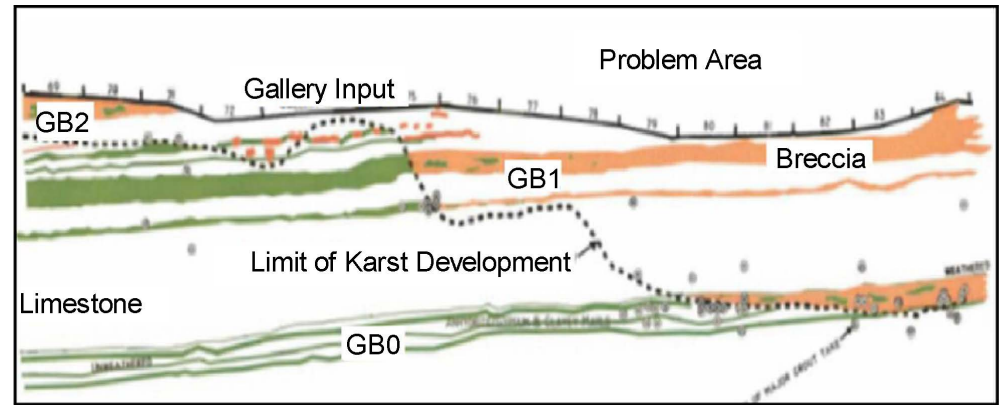

Figure 3. Karst line location under the dam.

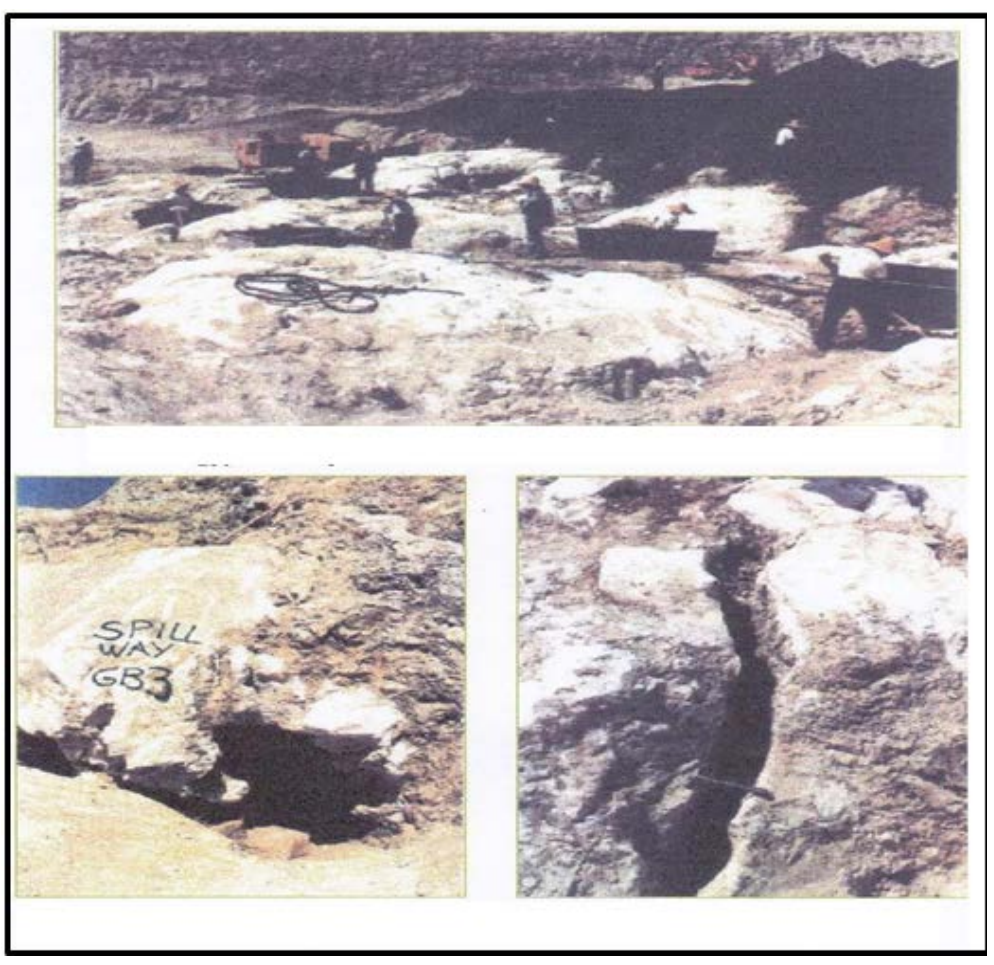

Figure 4. The badly jointed and fissured (GB3) layer found in the left bank in the foundation of the spillway chute and bucket [7].

It must be stated here that the designer used the karst line to define the depth of the grout curtain under the main dam. Under the saddle dam the curtain was taken through the (F-Bed) layer and partly through the (GB3) layer below.

Dam foundation in the right bank suffered from similar problems, but due to the inversion of the rock formations making the Wadi Malih anticline, itself forms the right abutment of the dam. Then the karst line at the end of the right abutment was very deep and any grout curtain would extend very deeply before hitting this line.

Figure 5 shows how a (GB) layer is formed. As it may be seen from the figure, a dissolution channel which may start as a crack in gypsum/anhydrite formation developers and enlarges continuously by the flow of seepage water to form a big cavernous channel which then collapsed and filled by limestone and gypsum breccias and cemented by clay from badly cracked marly layer from above [5]. 


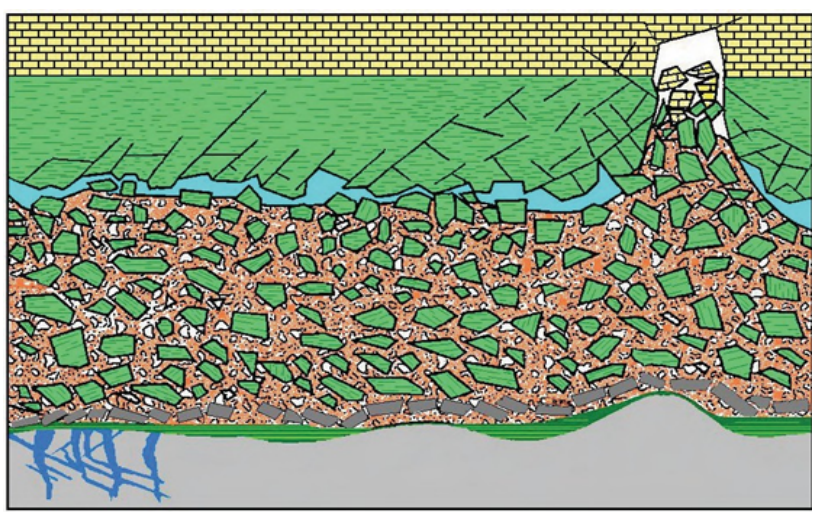

Figure 5. Formation of Gypsum breccias layer.

\section{Problems Encountered during Filling and Operation of the Reservoir}

In the left bank, heavy seepage and dissolution of gypsum were observed during the filling of the reservoir, and similar thing was occurring from under the main dam. Field measurements and calculations showed that a quantity of $(13,000)$ tons of salts had been dissolved and washed away during the period February-March 1986. Dissolution was progressing at a rate of $42-80$ tons per day. Remedial actions were taken to reduce the deterioration of rock formations in the left bank by strengthening the grout curtain under the saddle dam and adding another curtain parallel to the spillway chute to protect its foundation. These measures reduced seepage and dissolution but they could not stop them altogether. The photographs in Figure 6 show present day seepage outflows on both sides of the spillway [3] [6].

Grouting the curtain under the main dam was encountered by immense difficulties. Many areas in the (GB) layers could not be sealed in spite of repeated grouting by using different grout types and mixes. They were still open when the reservoir was impounded and they remained as chronic and bad spots till now. While maintenance grouting during the past almost 30 years had managed to close them temporarily they kept opening up every now and then to be plugged again and again. These maintenance operations conducted over the years have only lengthened the life of the dam, they are considered by experts as not going to save it in the long run. In fact the repeated grouting is causing the deterioration of the rock and causing the dissolution front to move and cover previously fewer karstified areas. One study performed in 2006 [8] concludes that this front had moved 350 meters eastwards. Stopping maintenance grouting altogether would, however, speed up the settlement of the dam and its eventual collapse.

We have observed such deterioration when maintenance grouting was forced to stop from July 2014 to the end of 2015 after ISIS had run over the site and caused the technical staff to flee the site. The grouting was resumed later in 2016 by an Italian company under the supervision of the United States Army Corps of Engineers (USACE). It must be emphasized here that maintenance grouting is not a permanent solution. During the years of operation dissolution phenomena 
around and close to the dam, there was clear evidence of the deterioration of the whole site. Figure 7 shows 1.3 meter high dissolution tunnel at the right rim of the reservoir which was formed in September 1986 close to a group of sinkholes in the same area after one year of starting impounding. Figure 8 shows a ground crack which appeared in 2002 very close to the right abutment resulting from the dissolution of gypsum layer beneath it. This was kept under observation and it

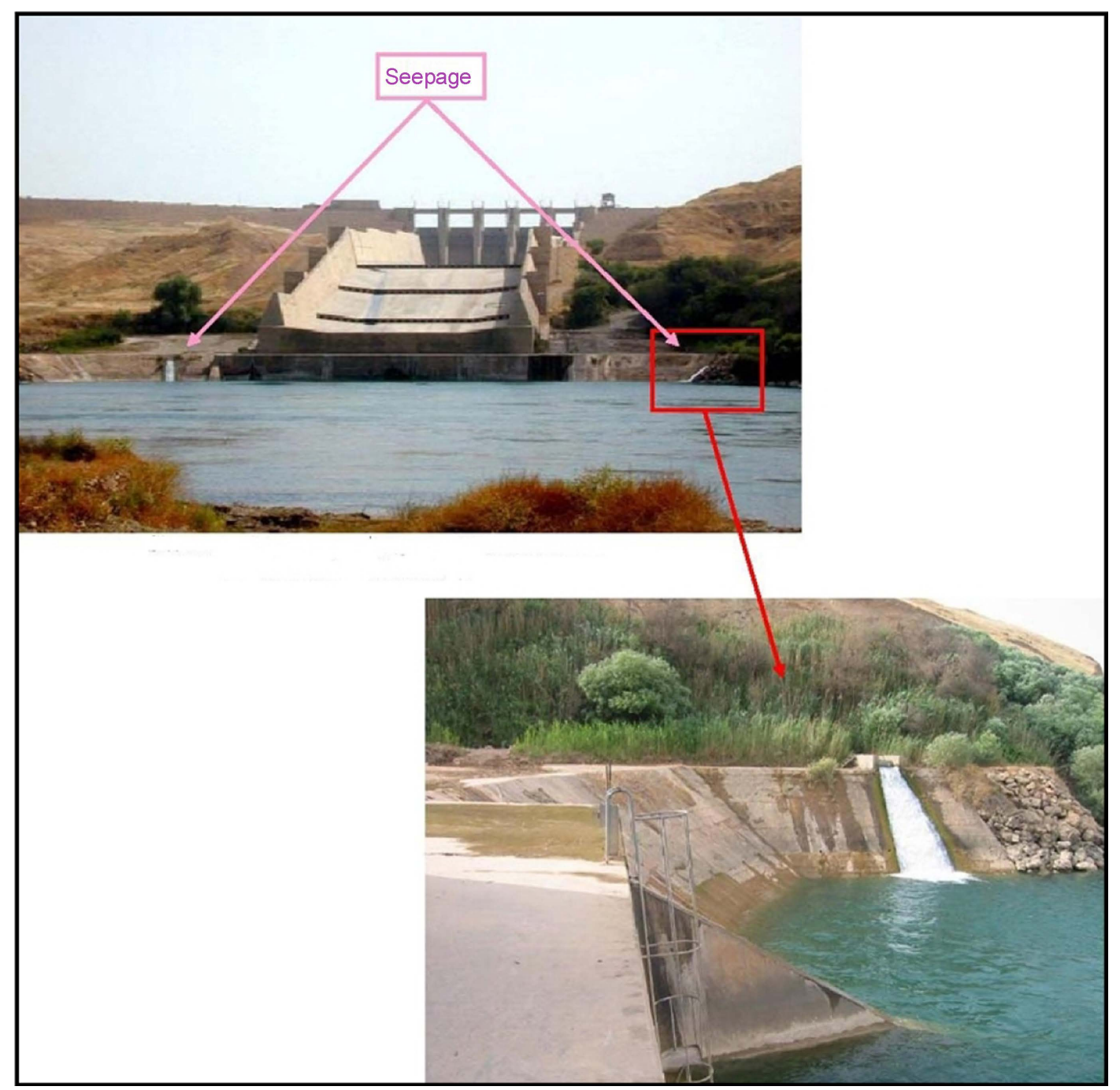

Figure 6. Outflow points of left bank seepage water [3] [6].



Figure 7. Dissolution tunnel observed in the right bank close to dam abutment [3]. 
stopped enlarging in 2004. Our interpretation of its opening is that it had resulted from the dissolution of a thin under layer of gypsum which was open to the reservoir. These and other observations indicate active dissolution at this side of the dam and very close it.

Sinkholes had also formed in both right and left banks downstream and close to the dam. Figure 9 shows the location of four very large sinkholes which had appeared in 1992 and continued to develop till 1998. After much research work, it was concluded that they have resulted from water inflow coming from Wadi Malih aquifer which was being fed from the reservoir and outflanking the dam. This seepage water had caused the dissolution of a gypsum bed below the sinkholes location. On the left bank and very close to the toe of the dam another sinkhole appeared suddenly in 2002. Figure 10 shows this sinkhole when it first appeared and after it was cleaned and measured. It took 4200 cubic meters of filling materials to fill it but continued to settle for another 0.5 meter in 2005 . The cause for this sinkhole was established after boring piezometers around it and conducting tracers dye tests. Seepage water coming from under the far end of the dam was responsible for dissolving a gypsum bed of (GB3) in this location leading to its formation.

In 2010 a bathymetric survey of the reservoir was conducted by a $\mathrm{PhD}$ student of Lulea University (Sweden). This survey showed a great number of sinkholes

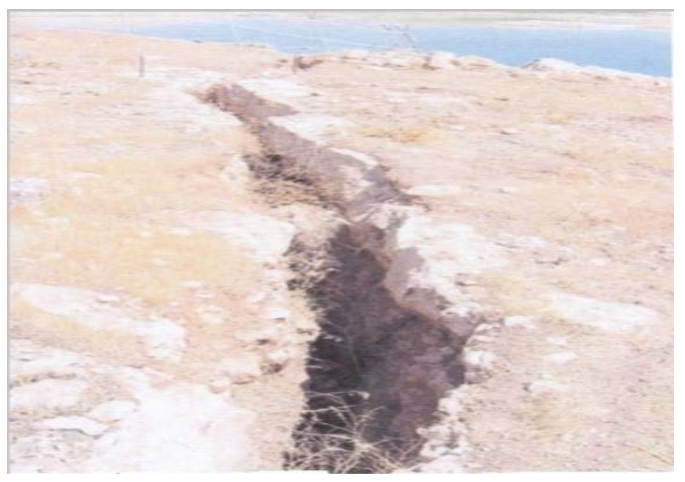

Figure 8. Ground fissure which appeared in the right abutment close to dam abutment [3].

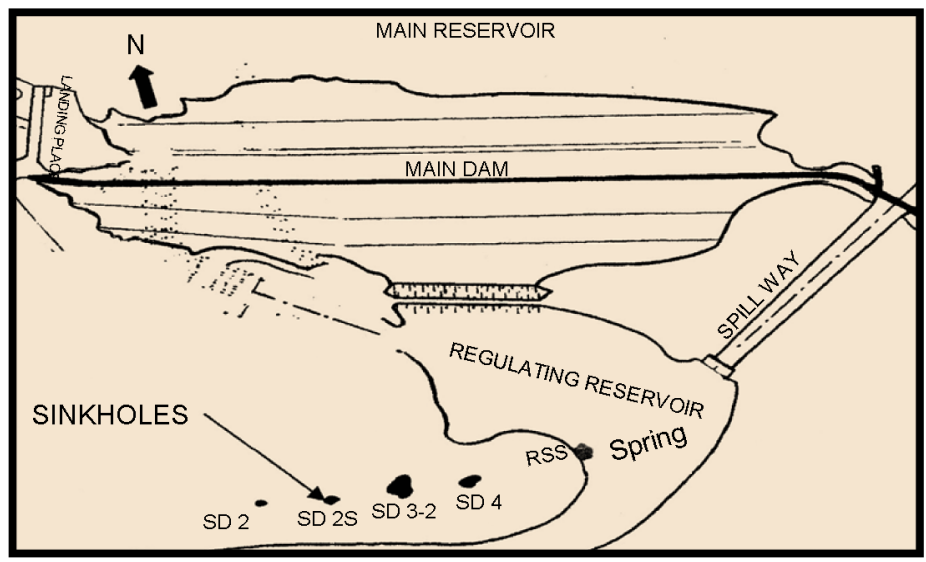

Figure 9. Location of sinkholes (1992-1998) [3]. 


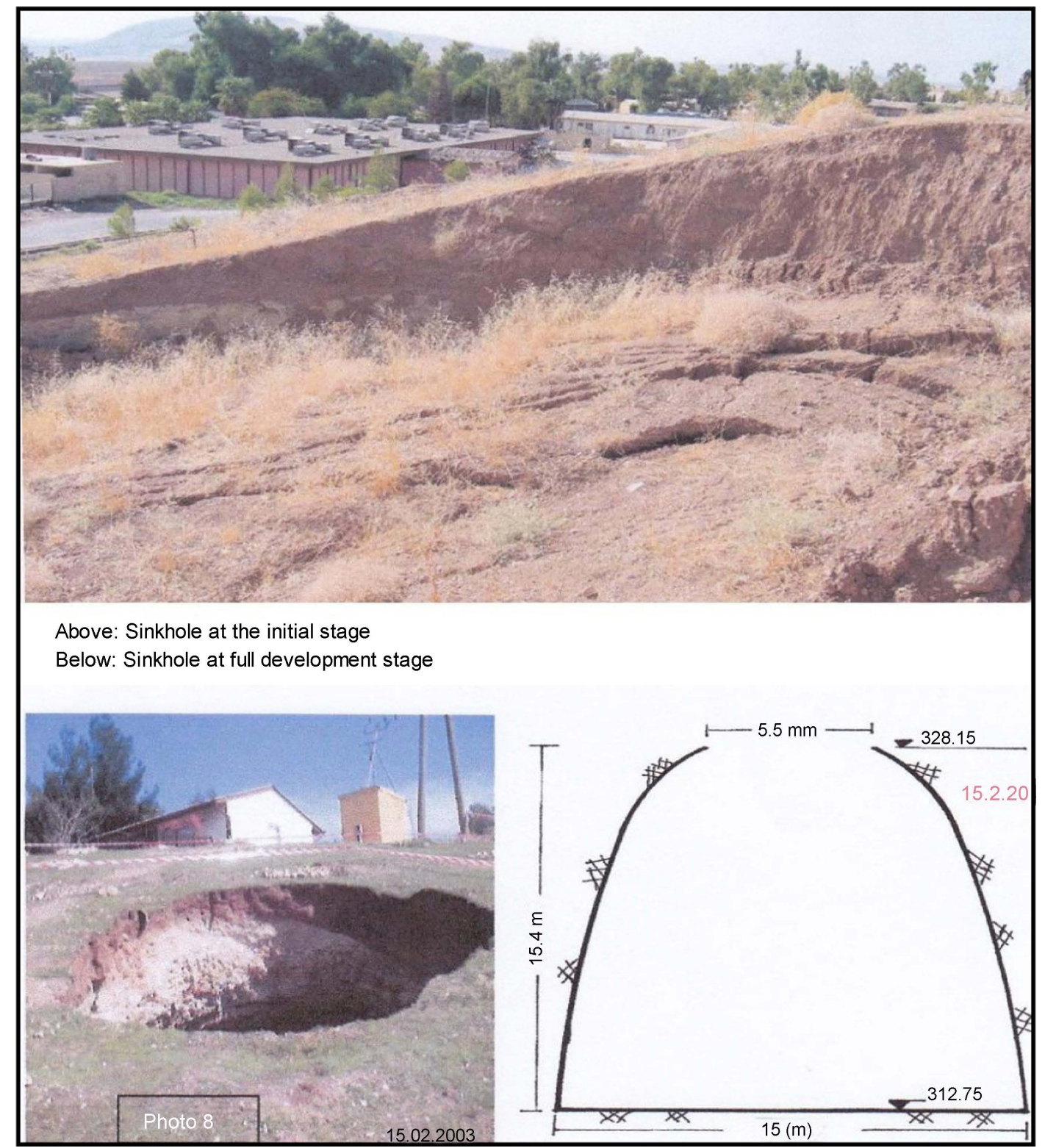

Figure 10. Sinkhole at left bank [4].

which had formed there (Figure 11). Some of these were as deep as 10 meters and were very close to the dam [9]. Such sinkholes pose a great threat to the dam if they are formed at the dam $\mathrm{u} / \mathrm{s}$ toes. This is due to the dissolution of gypsum and limestone beds forming the sinkholes and other karst forms within the reservoir, these forms will increase in size with time and exert hazards to the dam.

\section{Dams Experts Opinions}

In 2005 world leading experts working for the (Coalition Provisional Authority) expressed their deep concern over the dam conditions and the progression of deterioration of the foundations. They worked out several potential failure modes for the dam. The most probable ones were caused by dissolution in the foundation resulting in progressive settlement and cracking of the dam which 




Figure 11. Sinkholes in Mosul Dam Reservoir mapped in (2011) [9].

would lead eventually to its collapse [10]. In their elaboration they stressed that continuing maintenance grouting was good only in elongating the life of the dam but it will not stop its failure in the long run. They eliminated the alternative of constructing a diaphragm from the crest of the dam which would be (240) meter deep as being dangerous for the integrity of the dam, and that such large diaphragm was never tried before and it will be very costly. They concluded that the only alternative which could give full safety and coverage to the population downstream if the dam fails was the resumption of construction of the downstream unfinished Badush Dam. This dam was planned in the late eighties to act as a protection dam from Mosul Dam flood wave if it collapsed, but construction was halted in 1990 due to the economic sanctions imposed on Iraq due to its occupation of Kuwait.

In 2007, another group of experts appointed by the Ministry of Water Resources had an opposite view and considered the construction of the diaphragm as the only safe solution and abandoned Badush Dam as protection dam solution [11]. Another Consulting firm working for the ministry decided in (2014) that Badush Dam should be reinstated as protection dam after introducing some design modification [12].

Finally the authors who had formed a working group on Mosul Dam under the name of Mosul Dam Luellå University team since the middle of 2014 held an International workshop on 24 - 25 of May 2016 in Stockholm to discuss Mosul Dam problems, in order to come up with concrete proposals for final solution to these problems. Six leading world dam experts were invited to take part in the working of this workshop in addition to many other consultants and contractors representatives who participated actively in the discussions. The team input was a comprehensive presentation of the dam's problems, the consequences of its 
failure and a draft action plan for the measures to be taken and the solutions to be adopted. The final recommendations reached were either to install a diaphragm in Mosul Dam if a detailed study showed its positive economic and technical feasibility or, to continue grouting work and at the same time complete Badush Dam as a protection dam, as this dam was actually designed as a protection dam downstream from Mosul Dam but it was partially completed and unfortunately abandoned due to war conditions in 1991, or even to consider a hybrid solution whereby to complete Badush dam as a permanent replacement for Mosul Dam after modifying its design to act as a storage dam, and then release the Mosul Dam Storage gradually into Badush reservoir. And then abandonee Mosul Dam completely [13]. Mosul Dam still waits now for the final decision of the government on the permanent solution which should not be delayed due to its critical conditions.

\section{Present Dam Situation}

So it had happened that after ISIS was kicked out of the dam site in August (2014) maintenance grouting came to a halt due to security condition at the site. The rising concerns on the dam deteriorating foundation prompted the United States Army Corps of Engineers to step in and so forming an interagency team from other specialized agencies in (2015) to carry out checking of the dam's safety.

The team installed instruments and cameras to monitor movements of the dam structures and measured seepage and check gypsum concentrations in seepage water. The displacements were abnormally high, checking seepage flows and the dissolution of gypsum gave also alarmingly large quantities of both. At the end of (2015) the team accumulated enough evidence to prove that the dam was progressing rapidly to failure conditions. In their report completed by the end of that year they considered the dam as being on the verge of failure. Figure 12 gives the position of Mosul Dam on The USACE relative risk chart. Their Conclusion is shown in Figure 13 which is copied from their report.

Figure 12 and Figure 13 are extracted from a third party report [14]. The USACE original report was confidential and intended for official use only and we could not get it. So while we give these figures as indication of their work we cannot testify for their absolute validity or correctness. At the same time and as they come from a well respected and highly professional authority such as the USACE we cannot reject them either.

In a scientific report published in the magazine (Nature) on 6th December 2016 [15]. It proved from space geodetic monitoring that Mosul dam is suffering from an accelerated rate of vertical displacements and lateral movement since the stopping of maintenance grouting. The vertical displacement rate for the period 2004-2010 was $12.5 \mathrm{~mm} /$ year compared to $1.5 \mathrm{~mm} /$ year in 2014-2015 as shown in space monitoring images given in Figure 14. This study confirms the results of a previous study which was presented in a lecture given by Frano Cetinic from Globsar AS. Norway, to a Workshop on Mosul dam which was held 


\section{Relative Risk}

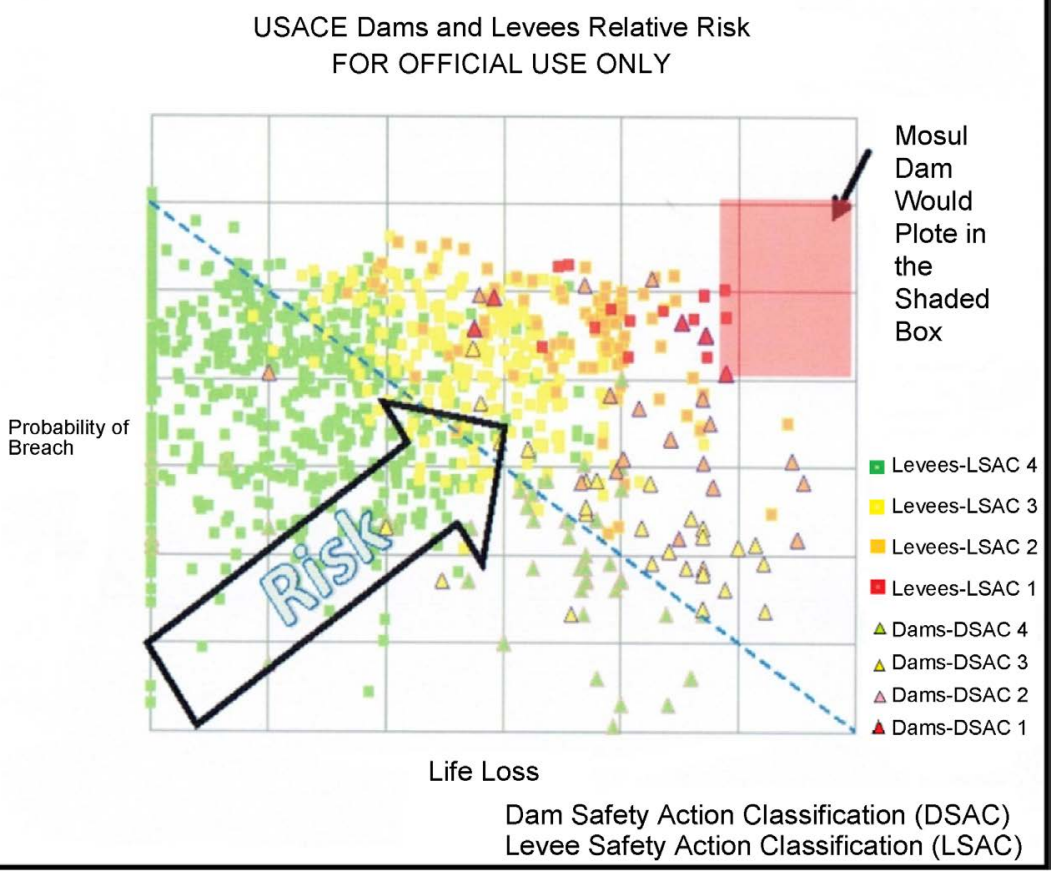

Figure 12. Mosul Dam on the USACE chart of relative risk.

\section{Conclusion}

Since coordinated monitoring of Mosul Dam began over a year ago, the interagency team monitoring the dam has identified significant signs of distress and potential failure progression that were not identified when post-ISIL monitoring began. All information gathered in the last year indicates Mosul Dam is at a significantly higher risk of failure than a year ago.

Figure 13. USACE conclusion on Mosul Dam as copied from their report.

by us as a team of Luleå university on $24-25$ May 2016. This study was utilized radar-satellite observation and imagery [16].

\section{Dimensions of the Catastrophe If the Dam Fails}

The first study on the potential Mosul Dam failure and the consequent flood wave was done in 1984 by the Swiss Consultants. It showed that a huge and destructive wave would commence and move in a fearful speed downstream in the river course flooding and destroying everything in its way down to Bagdad and beyond. While the study gave the discharge of the wave peaks, its depths and its times of arrival to selected points it did not attempt to quantify the human losses or the material damage which would result and which be colossal by all measures. Many other studies were performed in the last 30 years. The last study was done in 2016 when the Joint research Center in the European Commission (JRC) published their study report on this subject [17]. Table 1 gives the maximum height of wave, time of arrival of the wave, time of arrival of the peaks when various scenarios of reservoir levels were used at failure. Table 2 shows the 


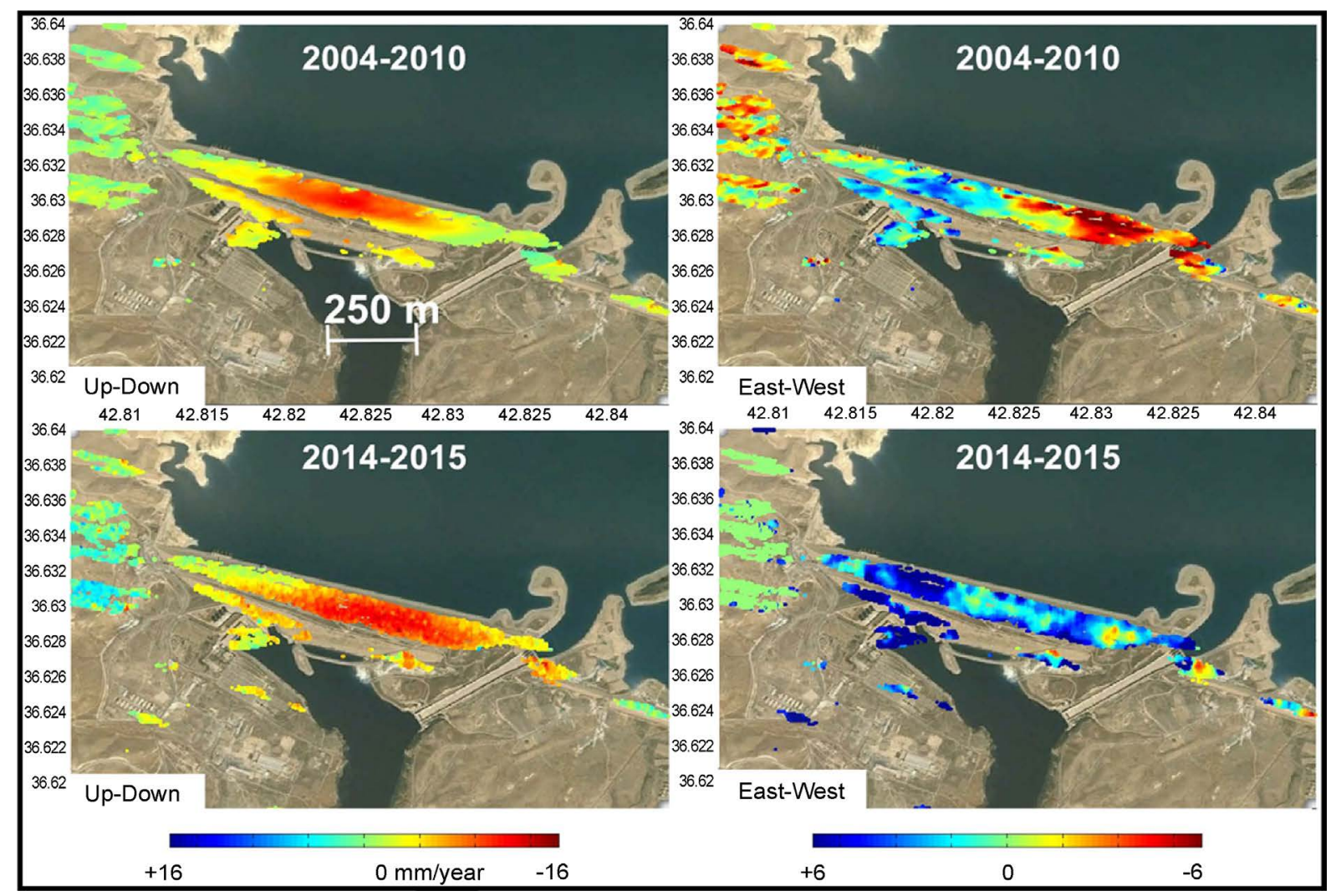

Figure 14. Photographs on the left indicate vertical movement. Photographs on the right show horizontal displacements. All in (2004-2010) and (2014-2014) [15].

Table 1. Maximum heights of wave and times of wave arrival and its peaks for various scenarios.

\begin{tabular}{cccccccccccccccc}
\hline City & \multicolumn{3}{c}{ Mosul } & \multicolumn{3}{c}{ Baeji } & \multicolumn{4}{c}{ Tikrit } & \multicolumn{3}{c}{ Sammara } & \multicolumn{3}{c}{ Baghdad } \\
\hline R.L & $\mathrm{T}_{1}$ & $\mathrm{~T}_{2}$ & $\mathrm{H}$ & $\mathrm{T}_{1}$ & $\mathrm{~T}_{2}$ & $\mathrm{H}$ & $\mathrm{T}_{1}$ & $\mathrm{~T}_{2}$ & $\mathrm{H}$ & $\mathrm{T}_{1}$ & $\mathrm{~T}_{2}$ & $\mathrm{H}$ & $\mathrm{T}_{1}$ & $\mathrm{~T}_{2}$ & $\mathrm{H}$ \\
\hline 330 & 1.7 & 6.2 & 26.3 & 16.8 & 23.5 & 14.3 & 21.08 & 26.8 & 14.5 & 26.12 & 30.08 & 16.1 & 67.0 & 67.0 & 8 \\
319 & 2.29 & - & 22.7 & 18.59 & - & 11.8 & 24.07 & - & 11.8 & 30.05 & - & 13.8 & 76.20 & - & 7.6 \\
309 & 2.55 & - & 19.2 & 22.54 & - & 9.3 & 29.00 & - & 9.5 & 36.48 & - & 11.1 & 96.40 & - & 7.5 \\
307 & 2.54 & - & 18.6 & 23.45 & - & 8.9 & 30.04 & - & 9.1 & 38.12 & - & 10.4 & 103.05 & - & 7.4 \\
305 & 3.17 & - & 17.9 & 24.53 & - & 8.3 & 31.19 & - & 8.7 & 40.12 & - & 9.9 & 111.31 & - & 7.3 \\
300 & 3.40 & - & 16.0 & 28,32 & - & 7.3 & 35.58 & - & 7,8 & 46.18 & - & 8.3 & 141.33 & - & 7.1 \\
\hline
\end{tabular}

R.L = Reservoir water Level (m.a.s.l.), $T_{1}=$ Time of wave arrival (hours), $T_{2}=$ Time of maximum wave height (hours), $\mathrm{H}=$ Maximum wave height (meters).

Table 2. Affected population and inundated areas for the various different water level scenarios when the dam fails for the period of inundation given.

\begin{tabular}{cccc}
\hline Reservoir Water Level (m.a.s.l) & Affected Population & Inundated Area $\left(\mathrm{km}^{2}\right)$ & Days \\
\hline 330 & $6,248,000$ & 7202 & 6 \\
319 & $4,263,000$ & 5757 & 6 \\
309 & $3,291,000$ & 3672 & 12 \\
307 & $3,052,000$ & 3923 & 12 \\
305 & $2,921,000$ & 3595 & 12 \\
300 & $2,205,000$ & 2791 & 12 \\
\hline
\end{tabular}


number of affected population and the inundated areas for the various water scenarios of storage water levels when the dam fails and for the period of inundation given.

The actual fatal casualties will be a high percentage of the affected population especially in towns not far down from the dam site; the remaining numbers will be displaced. The study also detailed the numbers of affected population in five selected cities for the same scenarios, but for brevity sake we give in Table 3 these numbers for the lowest reservoir level of 300 which is the dead storage level, and in five cities including Baghdad.

If Mosul Dam fails then the catastrophe which follows is by far beyond anything which had been experienced before or can be imagined to happen in the future.

\section{Conclusions}

Since the start of its operation in 1986, Mosul Dam is suffering from seepage problems under its foundation. Grouting operation did not stop the seepage but it kept the dam stable. Present situation seems to be worse than it was before. This is due to the fact that grouting operations stopped for a long period of time since ISIS occupied the dam in 2014 which caused the dissolution of about $10,000 \mathrm{~m}^{3}$ of gypsum. In addition, gypsum breccias layers are very much resistant to grouting.

To overcome the problems immediate action is to be taken. In this context, it is evident that grouting cannot solve the seepage problem but it can elongate the span life of the dam. Therefore, it is necessary to:

a. Continue an intensive grout schedule to gain time to execute a final solution.

b. Keeping the water level at the reservoir as low as possible to avoid the increase of the solubility of gypsum and minimize the failure consequences.

c. Emergency action plan and early warning system are to be established and made public.

d. Bathymetric survey upstream the dam should be conducted to see if there are existing sinkholes within the vicinity of the dam from the reservoir area.

e. A panel of experts is to be established and it should meet every 3 months to evaluate the condition of the dam.

Table 3. This table gives the number of affected population at various depths of inundation for dam failure scenario at level (300).

\begin{tabular}{ccc}
\hline Inundation & Population & Area $\left(\mathrm{Km}^{2}\right)$ \\
\hline $0.1-0.5 \mathrm{~m}$ & 984,000 & 637 \\
$0.5-2.0 \mathrm{~m}$ & $3,144,000$ & 2022 \\
$2-5 \mathrm{~m}$ & $1,626,000$ & 2482 \\
$5-10 \mathrm{~m}$ & 260,000 & 1150 \\
$>10 \mathrm{~m}$ & 270,000 & 916 \\
Total & $6,248,000$ & 7202 \\
\hline
\end{tabular}


f. Final solution should be carefully taken which includes either the completion of the alternative Badush Dam or construction of a diaphragm in Mosul Dam as explained in the previous paragraph.

\section{Acknowledgements}

The authors would like to thank all the individuals that contributed in their discussions and comments during the Mosul Dam workshop that was held in Stockholm 24 - 25 May 2016. Special thanks and gratitude to Dr. Jean-Jacque Fry (Dam Safety Engineer, Electricité de France-EDF), Dr. Jonathan Fannin (Professor, University of British Columbia), Dr. Leif Lia, NTNU (Professor, Norway), Dr. Markus Aufleger (Professor, University of Innsbruck, Austria), Urban Norstedt (U Norstedt MTF AB, former dam safety expert at Vattenfall Hydropower company, Sweden), Dr. Robert Cannon (Principal in Dam Engineering at Schnabel Engineering, North Carolina, USA), Dr. Peter Banzhaf (BAUER, Head Dam Services, Germany), Dr. Frano Cetinic (Globesar, Norway) and Mr. Ismail Mustafa Aljanabi (previously Ministry of Water Resources, Baghdad) for their fruitful discussions, comments and suggestions during and after the Mosul Dam workshop.

\section{References}

[1] General Directorate of Dams (1980) "Mosul Dam Project". Collection of Reports and Studies on Mosul Dam for the period 1952 -1980. Library of the General directorate of dams and Reservoirs. Ministry of Water Resources, Baghdad, Iraq.

[2] Saddam (1989) (Mosul) Dam Project Main Scheme-Final Report \& As Built Drawings. Swiss Consultants Consortium, Baghdad.

[3] Adamo, N. and Al-Ansari, N. (2016) Mosul Dam Full Story: Engineering Problems. Journal of Earth Sciences and Geotechnical Engineering, 6, 213-244.

[4] Washington Group International \& Black and Veatch. (2005) Mosul Dam StudyTask Order No 8. Final Report, Washington, 156 p.

[5] Warren, J.K. (2006) Evaporites: Sediments, Resources and Hydrocarbons. Springer-Varlag, New York.

[6] Special Inspector General for Iraq Reconstruction. (2007) Relief and Reconstruction Funded Work at Mosul Dam, Mosul, Iraq.

[7] Wheeler, A. (2004) Mosul Dam Assessment-Report on Site Visit, Baghdad. Iraq.

[8] Kelly, J.R., Wakeley. L.D., Broadfoot, S.W., Pearson, M.L., MaGrth, C.J., McGill, M.T., Jorgeson, J.D. and Talbot, C.A. (2007) Geologic Setting of Mosul Dam and its Engineering Implications, USACE-Engineer and Development Center, Vicksburg.

[9] Issa, I.E. (2015) Sedimentological and Hydrological Investigations of Mosul Dam. $\mathrm{PhD}$ Thesis, Department of Civil Engineering and Natural Resources Engineering, Lulea Technical University, Lulea.

[10] Washington Group International \& Black and Veatch (2005) Mosul Dam Study -Task Order No 8. Final Report. Potential Failure Mode-Appendix Journal Analysis.

[11] MWH Mosul Dam Panel of Experts (2007) Mosul Dam, Issues and Challenges. Report No3, Amman.

[12] EDR Engineering Consultants, Team International (2014) Badush Dam, Final Fea- 
sibility Study Report.

[13] Adamo, N. and Al-Ansari, N. (2012) Mosul Dam Full Story: Safety Evaluations of Mosul Dam. Journal of Earth Sciences and Geotechnical Engineering, 6, 185-211.

[14] Al-Abayachi, S. (2016) Report on Mosul Dam. The Agriculture, water, and Marshes Sub-Committee, Iraqi House of Representatives. https://drive.google.com/file/d/0Byn0PFg9wZ5FNHNQUmxLb0JzenM/vie

[15] Milillo, P., Burgman, R., lundgren, P., Salzer, J., Perissin, D., Fielding, E., Biondi, F. and Milillo, G. (2016) Space Geodetic Monitoring of Engineered Structures: The ongoing Destabilization of the Mosul Dam, Iraq. Scientific Report, Nature Magazine, Pasadena. http://www.nature.com/articles/srep37408

[16] Cetinic, F. (Year) Satellite Based Information to Support Health Analysis of Mosul Dam. International Workshop on Mosul Dam, Stockholm, 24-25 May 2016.

[17] Annunziato, A., Andredakis, I. and Probst, P. (2016) Impact of Flood by a Possible Failure of the Mosul Dam. JRC Technical Reports, EU Commission.

\section{Submit or recommend next manuscript to SCIRP and we will provide best} service for you:

Accepting pre-submission inquiries through Email, Facebook, LinkedIn, Twitter, etc. A wide selection of journals (inclusive of 9 subjects, more than 200 journals)

Providing 24-hour high-quality service

User-friendly online submission system

Fair and swift peer-review system

Efficient typesetting and proofreading procedure

Display of the result of downloads and visits, as well as the number of cited articles

Maximum dissemination of your research work

Submit your manuscript at: http://papersubmission.scirp.org/

Or contact eng@scirp.org 